\title{
Territorial governance and social innovation in regional development processes in mining territories: a theoretic model under construction
}

\author{
Paula Pessoa de Castro Gentil ${ }^{1}$ \\ LILIANE de OLIVEIRA GUIMARÃES ${ }^{1}$ \\ Denise de Castro Pereira ${ }^{2}$ \\ AlexandRe Magno DinIZ ${ }^{3}$ \\ IVAN BECK CKAGNAZAROF ${ }^{4}$
}

\author{
${ }^{1}$ Pontifícia Universidade Católica de Minas Gerais (PuC Minas) / Programa de Pós-graduação em Administração, \\ BELO HORIZONTE - MG, BRAZIL \\ 2 Universidade Federal de Minas Gerais (UFMG) / Grupo de Estudos em Temáticas Ambientais, Belo HoRIZONTE - MG, BRAZIL \\ ${ }^{3}$ Pontifícia Universidade Católica de Minas Gerais (PuC Minas) / Programa de Pós-graduação em Geografia, \\ BELO HORIZONTE - MG, BRAZIL \\ ${ }^{4}$ Universidade Federal de Minas Gerais (UFMG) / Centro de Estudos e Pesquisa, Departamento de CiênCIas Administrativas, \\ BELO HORIZONTE - MG, BRAZIL
}

\begin{abstract}
There are serious contradictions between the proclaimed economic benefits obtained by localities where the mineral extraction industry historically operates, and the results recorded in research work. Studies have pointed out serious problems and negative consequences from the mineral extraction industry's questionable form of management and relationship with the local environment. These practices have increased the socioeconomic and environmental vulnerability of the territories, both in local and regional dimensions. Studies about development indicate the existence of a positive relationship between governance and economic growth, and between innovation and economic growth. There are also studies that point out innovative processes as essential to local and regional development because they prioritize the territorial diversity and develop opportunities focused on the profile of each region. However, this discussion is still restricted to the economic and exclusive point of view of the industrial sector, which limits the analysis from the perspective of regional development. To unravel the nature of the still unclear relationship between territorial governance and social innovation and the effects of this relationship in regional development processes in mining territories, this article raises a set of six theoretical propositions, which forms a schematic model for further empirical investigation. The aim is to use this model to search for similarities and peculiarities, and to establish parallel or comparative analysis between diverse and different case studies.
\end{abstract}

Keywords: Territorial governance. Social innovation. Regional development. Mining territory.

Governança territoriale inovação social nos processos de desenvolvimento regionalem territórios de mineração: um modelo teórico em construção

Resumo

Há uma grave contradição entre os apregoados benefícios econômicos gerados para as localidades onde se instala e onde subsiste historicamente a indústria extrativa mineral e os resultados registrados em estudos, que apontam sérios problemas e consequências negativas decorrentes da sua questionável forma de gestão e relacionamento com o ambiente local, o que têm ampliado a vulnerabilidade socioeconômica e ambiental dos territórios, nas dimensões locais e regionais. Em estudos sobre desenvolvimento, análises indicam a existência de uma relação com resultados positivos entre a governança e crescimento econômico, e entre inovação e crescimento econômico. Há estudos que apontam ainda os processos inovadores como essenciais ao desenvolvimento local e regional, ao priorizar toda a diversidade territorial e desenvolver oportunidades voltadas para o perfil de cada região. Mas essa discussão ainda está muito restrita ao ponto de vista econômico e exclusivo do setor industrial, o que limita a análise sob a perspectiva do desenvolvimento regional. Com o intuito de desvendar a natureza da relação ainda pouco explorada entre a governança territorial e a inovação social e os efeitos dessa relação nos processos de desenvolvimento regional em territórios de mineração, apresenta-se neste trabalho um conjunto de seis proposições teóricas, que formam um modelo para posterior investigação empírica, em que se possa buscar semelhanças e especificidades, e estabelecer paralelos ou análises comparativas entre estudos de casos.

Palavras-chave: Governança territorial. Inovação social. Desenvolvimento regional. Território de mineração.

Gobernanza territorial e innovación social en los procesos de desarrollo regional en las zonas mineras: un modelo teórico en construcción

Resumen

Hay una seria contradicción entre los pregonados beneficios económicos generados a las localidades donde se encuentra y donde históricamente subsiste la industria de la minería, y los resultados reportados en estudios, que indican problemas graves y las consecuencias negativas de su cuestionable forma de gestión y su relación con el ambiente local, lo que ha ampliado la vulnerabilidad socioeconómica y ambiental de los territorios en las dimensiones locales y regionales. En los estudios sobre el desarrollo, los análisis indican la existencia de una relación con resultados positivos entre la gobernanza y el crecimiento económico, y entre la innovación y el crecimiento económico. Los estudios también indican los procesos innovadores como esenciales para el desarrollo local y regional, al priorizar toda la diversidad territorial y desarrollar oportunidades orientadas al perfil de cada región. Sin embargo, esta discusión está todavía muy restringida al punto de vista económico y exclusivo del sector industrial, que limita el análisis desde la perspectiva del desarrollo regional. Con el fin de desentrañar la naturaleza de la relación aún poco explorada entre la gobernanza territorial y la innovación social y los efectos de esa relación en los procesos de desarrollo regional en las zonas mineras, se presentan en este trabajo un conjunto de seis propuestas teóricas, que forman un modelo para una posterior investigación empírica en la que se pueda buscar semejanzas y especificidades, y establecer paralelos o análisis comparativos entre los estudios de casos.

Palabras clave: Gobernanza territorial. Innovación social. Desarrollo regional. Territorio de minería.

Article submitted on February 05, 2018 and accepted for publication on November 29, 2018.

[Original version]

This study was financed in part by the Coordenação de Aperfeiçoamento de Pessoal de Nível Superior - Brasil (CAPES) - Finance Code 001 and Projeto FAPEMIG/Conseil Régional NPDC - APQ-03544-15, "Wealth Through Sharing - Riquezas Compartilhadas".

DOI: http://dx.doi.org/10.1590/1679-395173778x

Cad. EBAPE.BR, v. 17, nº 3, Rio de Janeiro, July/Sept. 2019. 
Territorial governance and social innovation in regional development processes in mining territories: a theoretic model under construction
Paula Pessoa de Castro Gentil | Liliane de Oliveira Guimarães Denise de Castro Pereira | Alexandre Magno Diniz Ivan Beck Ckagnazarof

\section{INTRODUCTION}

Despite the current institutional speech about the importance of mineral extractive activity and the proclaimed local economic benefits to mining territories (DEPARTAMENTO NACIONAL DE PESQUISA MINERAL [DNPM], 2015; INSTITUTO BRASILEIRO DE MINERÇÃO [IBRAM], 2012; CENTRO DE GESTÃO DE ESTUDOS ESTRATÉGICOS [CGEE], 2002), studies results state severe problems arising from its questionable forms of management and relationship. They have increased socioeconomic and environmental vulnerabilities of territories, at local and regional levels (LAMBERT and BOULANGER, 2001; EJDEMO and SODERHOLM, 2011; BECKER and PEREIRA, 2011; BITTENCOURT, 2014; VILLELA and GIUSTI, 2016; BORGES, 2018). Issues that correlate the mineral extraction activity with overcoming poverty, improving human capital, fair income distribution and efficient use of mineral revenues and correlated themes are part of the agenda of discussions in many parts of the world (ENRIQUÉZ, 2007). Studies on mining activity territories stress the false notion of wealth and prosperity surging from the idea of capital accumulation and revenue production, strongly in institutional speech about the development of mining territories (CHAUTARD and ZUINDEAU, 2001; LIEFOOGHE, 2005; CHAPAIN and MURIE, 2008; DAVIS, 2009; RASUL and SHARMA, 2014).

In new regional development processes in mining territories, many actors have questioned how governments, businesses and communities could take economic and social opportunities from the development of natural capital of a region, while, at the same time, seeking to solve conflicts and problems, to ensure a more balanced and even-handed present and a future condition that is better than before the mineral extractive process began (MILANEZ and OLIVEIRA, 2009; ECHEVARRIA, 2001), under economic, social and environmental viewpoints, especially at local and regional levels. The goal of this paper is answering the question by passing through the governance. Governance as a new social, political and institutional way of organizing the territory. Governance as a conductor of an articulated social process, with dialogue, negotiation and indulgence between actors of various levels. Governance as a designer of local autonomy and for the social transformation (FARIA and ARAUJO, 2015). As complementary hypothesis, it is assumed that a likely trigger for this transformation would be social innovation process interspersed with territorial development dynamics (NUSSBAUMER and MOULAERT, 2004; LEVÉSQUE, 2011; CREVOISIER, 2014).

Thus, as the methodological proceedings, a theoretical research (DEMO, 2000) or exploratory bibliographical research (SANTOS, 1999; GIL, 2001) was done firstly and presented in this theoretical paper. Part of the literature on regional development, territorial governance and social innovation themes were analyzed, in some cases especially about mining territories. The main issues and questions on each theme were pointed out. Based on them, six theoretical propositions were elaborated and then stated, relating the key issues revealed in each theme, with the purpose of building a theoretical model for later empirical research, which is presented in the last part of the paper. By doing so, it will allow future studies to draw parallels or make comparative analysis, relating the governance and social innovation processes, through case studies of different regional development situations in mining territories (GODOY, 1995; GODOI and BALSINI, 2004; SOY, 1997; EISENNHARDT, 1989; GREENWOOD, 1973; GOODE and HATT, 1973).

\section{THEORETICAL REFERENCES AND DISCUSSION}

\section{The regional development in mining territories}

The mining activity has strong impact on territories, in all development steps, from the project and beginning of a venture, including its operation and its end, and even after its closure. As for an economic point of view, the studies on the entry of a mineral venture in a region often emphasize economic growth results based on measures to increase employment and on the production of public revenue, as well as internal industry data, such as production, sales volume, export and investment forecast (DNPM, 2015; IBRAM, 2012). Based on these data, the institutional speech claims that the mining is considered as a "[...] fundamental activity for the economic and social development of many countries, so that the minerals are essential for modern life [...]" (CGEE, 2002, p. 3). From the point of view of critical studies to extractive industry, composed of socioeconomic analysis, the entry of a mineral venture in a region, especially in rural and peripheral areas, or in small municipalities, are especially powerful. It often imposes different dynamics of appropriation and territorial use 
Territorial governance and social innovation in regional development processes in mining territories: a theoretic model under construction
Paula Pessoa de Castro Gentil | Liliane de Oliveira Guimarães Denise de Castro Pereira | Alexandre Magno Diniz Ivan Beck Ckagnazarof

as customary, including economic, social and political dynamics. There is nothing unusual about landscape degradation, exposed soil to erosion, suppression of vegetation, probable scarcity of wildlife, impaired water resources, the probable generation of large amounts of waste, and a significant migratory flow to the region, exacerbation of economic inequalities altering cultural references and horizons, and the growth of social pathologies such as alcoholism, gambling, prostitution and violence (SILVA, SILVA, FERREIRA et al., 2016).

In these cases, the conversion of the territory is immediately performed, and is characterized during the operation of mining ventures by "dismantling the lifestyle, by the disruption imposed on ecosystems, by weakness or absence of the governance mechanisms, especially related to local power and public organizations involved with the dual dimension of economic development and sustainability of this development" (PEREIRA and PEREIRA, 2012). Especially in highly dependent, or monoindustrial, mining cities, specialization may eventually lead to a decline in social welfare, at times of recession, and social tensions. The workforce becomes homogeneous and work is carried out in risky environments and damage to workers' health. Local business activity is low, with little participation of the small business sector, and consequently low diversification of the social and labor sphere, and of the economy in general (ARTUKHOVA, ROSHCHINA, KALYANOVA et al., 2018). With the implementation of mineral exploitation projects, nature and its natural resources take on a heavy toll as much is demanded from them and the shortage of natural resources is immediately transfigured, especially water scarcity and contamination (SILVA, SILVA, FERREIRA et al., 2016). Even after the closure of mines, the social problems and environmental consequences generated during the exploration phase still persist in the territory.

Two structures in particular have been related to mining regions in development strategies decision processes: the enclaves, as barriers to the development, and clusters, as strategic proposals. The concept of mineral enclave was very used, but has gradually been abandoned during the 1970, to be retaken at the 2000s. From the beginning of 1990, the promotion of clusters has been proposed in several mining regions around the world (ARIAS, ATIENZA and CADEMARTORI, 2014; AVILA, 2001; BUITELAAR, 2001).

Traditionally, the mining regions, especially in developing countries, produce an economic structure known as enclave. It is characterized by the presence of a multinational in a mining area, with weak productive relations with local companies, owned by foreign capital and exporter of low or no value-added goods, which leads to a vicious circle (ARIAS, ATIENZA and CADEMARTORI, 2014). The established privileges form solid barriers to any change movement. It can be contrary to the development and come to the risk of bankrupting any innovation attempt. The phenomena known as "lock-in" and "path dependence" are forms of enclaves. They prove that consolidated mechanisms reinforce the trajectory, historical quotas and emergencies that have effect of reinforcement, which directs a territory for a given path. This makes the new ideas result "[...] in small victories" and remain "peripheral [...]" (COENEN, MOODYSSON and MARTIN, 2014, p. 862).

The mining clusters received little attention from literature, which is based on the experience of manufacturing regions. The most common concept of clusters is a geographic concentration of companies and institutions around an industry where an endogenous process of innovation or improvement of competitive advantages enhances. Although it appears in the literature as a proposal for development, the cluster structure does not seem to be suitable to the mining activity reality. The mining operations are not organized into small and medium-sized enterprises network specialized in the same activity. On the contrary, the mining regions are characterized by the presence of large companies, multinationals, which dominate the local economy (central), oriented for exportation. It has, in its surroundings, a series of local suppliers of goods and services (rays), in a design closer to radial network districts (hub and spoke) (MARKUSEN, 1995; ARIAS, ATIENZA and CADEMARTORI, 2014; BUITELAAR, 2001).

Studies on regional development processes in mining territories reveal some particular characteristics that are identified as characteristics of the process, as the territorial impermeability to the so-called benefits arising from mining activity. Besides, mining operates focused on their own interests. Unclear vision and clouded diagnostics beyond the economic viewpoint support the business plans, which lead to the infeasibility of lasting social results. Public policies tend to be misaligned. The state government place itself in a distant or silent position to conflict issues, revealing its "false neutrality". Representatives of the local population are excluded or relegated to a marginal position in the decision-making process (LAMBERT and BOULANGER, 2001; EJDEMO and SODERHOLM, 2011; BECKER and PEREIRA, 2011). Additionally, the environmental costs of development are unequally distributed in the territory and within the population, because they tend to focus on areas already degraded 
Territorial governance and social innovation in regional development processes in mining territories: a theoretic model under construction
Paula Pessoa de Castro Gentil | Liliane de Oliveira Guimarães Denise de Castro Pereira | Alexandre Magno Diniz Ivan Beck Ckagnazarof

and nearby where are the poor people. This factor has been treated with detail by studies on principles of environmental justice. The social problems generated since the beginning of the mining activity, and perpetuated during its action, summed up the environmental consequences that linger in the post mining, which integrates the concept of "ecological inequality" (SCHMITT, 2007). The term facilitates the understanding of process that unleashes in regions if mining activity such as the exposure to natural hazards and technicians, degradation of life quality, the relative deprivation of certain goods and services commonly restrict or change the access to vital resources of the communities, resulting, in turn, in a decrease of potential development of the territory.

The main dilemma of cities and regions in their planned development processes has been to choose between the diversification and the increased dependence on mining, as in specialization experiences (CUNHA and GUEDES, 2017). In theoretical discussions and practical experiences about planned processes of territorial development, in a more comprehensive viewpoint, it is suggested that choosing the appropriate strategy represents a predominant factor to reach development results, since it cannot be transplanted or copied from one place to another. This strategy's selection is partly shaped by local power relationships and local institutional configuration, besides cultural characteristics and history (TAVARES, 2011; AFFUSO, CAPELLO and FRATESI, 2011; WALSH and ALLIN, 2012; BAETEN, SWYNGEDOUW and ALBRECHTS, 1999). However, empirical studies record the ignorance or disregard history and culture as part of the identity of a territory (ROCHA and ALMEIDA, 2005; HAESBAERT, 2007; SHILLING, 2008). In formal planning initiatives to develop a territory, very little has been observed about the past as a constituent of local culture and identity (ROCHA and ALMEIDA, 2005; HAESBAERT, 2007) and a strong bet has been made in the change and innovation and its transforming capacity (REIS, PASSONI and SHIKIDA, 2013).

Cases reported in some countries in Europe and in the United States have adopted strategies of urban centers integration or reintegration as competitors in the national and international market, aimed at overcoming economic crisis situations, in economic conversion processes. Each situation of degradation or abandonment of a city or region was treated by a different structure or social arrangement, oriented by a distinct proposal for management or confrontation. Having different orientations means different solutions, and so different strategies, intervention actions and, later, diverse consequences (BENTLEY, 2005; BAETEN, SWYNGEDOUW and ALBRECHTS, 1999).

The years 1980 register the emergence of practices based on planned intervention processes in Brazil, at the beginning focused on urban and big cities. Smaller and rural places were later included in the urban development plans, due to expansion of production and logistical connections to influence tourism industry (SANT'ANNA, NELSON, CAMPOS et al., 2011; FISCHER, 1996). The most visible effects of these interventions have still been in the economic field, but a few studies have also registered the consequences also in social, cultural and environmental fields, within an extended design development. In the mid-1990s, Brazil received the intervention orientation practices to development territories, especially cities and regions (DALLABRIDA, BUTTENBENDER, ROVER et al., 2009).

In general, the terms "restructuring" and "diversification" are related to strategies for regional development, most of the times by the viewpoint of economic growth. "Reconversion" has been used in studies related to coping the decay and/ or the decline, or even the abandonment of activities that moved the economy of urban cities or territories in the past and in the present are replaced by others, or updated under new parameters, always related to economic development initiatives (SANT'ANNA, NELSON, CAMPOS et al., 2011). There are similar concepts of conversion, such as restructuring (LEFEBVRE, 1993), used by other areas of research, like architecture, economy, sociology and the strands of sustainability studies, among others.

The term "diversification" concerns a specific strategy of economic growth and development of regions or industries that seek a better competitive status, usually based on the construction of historical forces and in identifying new opportunities (CAMAGNI, 2002; AFFUSO, CAPELLO and FRATESI, 2011). Such initiatives may or not be part of strategic plans of business or public management, composing a multidimensional process, which can be analyzed under different optical, either complementary or contrasting one.

It can be affirmed, therefore, the existence of specific characteristics in the different processes of development in mining territories. There are unique characteristics in each territory from the point of view of mineral resources, ecosystems, social, cultural, economic and political systems and dynamics, the history of human occupation, the local capacity to 
Territorial governance and social innovation in regional development processes in mining territories: a theoretic model under construction
Paula Pessoa de Castro Gentil | Liliane de Oliveira Guimarães Denise de Castro Pereira | Alexandre Magno Diniz Ivan Beck Ckagnazarof

absorb the changes of global markets, the formation of the society, the political organization, the dynamics of power and relationships between social groups, and the way mining activity is carried out, among others. But above all, there are common characteristics in different development processes, related to the mineral extraction activity in general and the relationship and positioning of the mineral sector in the territories. So, historically established privileges often constitute strong barriers to any movement of change, which may act in a way that is contrary to the development movement, and even go as far as to risk attempts to change. Questions exposed-in point to the first two theoretical propositions, which are: (i) Some specific characteristics of a mining territory can limit and even prevent its regional development. Therefore, (ii) the strategy for regional development in a mining territory should seek a priori mechanisms to minimize local dependency and negative influence of the mining activity.

The planned intervention of change is not only based on economic pillars. Planning calls for a governance that articulates the different social segments, and, consequently, different actors on different fronts of initiatives, with varied social interests, together and connected in joint work or in fronts of action. Strategic articulation is one of the focal points of the development process.

\section{Territorial governance and regional development}

The reflective questioning often made by multiple actors surrounding regional development processes, especially in mining territories, is how governments, businesses and communities could seize the economic and social opportunities arising from the development of the natural capital of a region, due to ensure a more balanced and equitable present and a future that could be better than it was before extracting the minerals? (MILANEZ and OLIVEIRA, 2011; ECHEVARRIA, 2001). It is known that the mineral productive chain unequally distributes the benefits provided by it, which compromises the territorial development policy. Therefore, it may not be prudent to seek such a response in strengthening or even transforming mining activity, at the cost of repeating dependency and impeding local autonomy. The focus of this theoretical model is that the answer to this question is beyond territorial governance. Considering governance as a political and institutional way of organizing the territory, as a driver of processes of articulation, dialogue, negotiation and agreement between actors at different levels, as a designer for local autonomy and for transformation (FARIA and ARAUJO, 2011). The models derived from corporate governance do not seem appropriate to solve problems or build collective future plans, which is exactly the purpose of the planned territorial development processes. One of the shortcomings would be the "political weakness" (BRUGUÉ and GOMA, 2007) engineered in these models. This weakness comes from the discrediting and the disaffection to the political issue. Without politics, you cannot manage conflicts or build shared projects. Therefore, it is necessary to create a new "administrative technology", one that could be capable of responding to new problems in society. One of the bets for this new technology consists of the dialog, through deliberation, and especially through participation (BRUGUÉ and GOMA, 2007).

For implementing the promises made by the territorial approach of development policies, the delimitation of a territory planning must take into consideration substantial and valuable aspects, as the common identity of the region by the involvement of regional actors, and is not solely defined either by technical criteria or from objectives that had been guided by state intervention. Also, you must take into consideration the historicalness of the territory, its contradictions and dominant relations (KRONEMBERGER, VELLELA and ZANI, 2012). One of the paths for this is through participation, which seeks to give not only legitimacy, but, above all, reality to support processes. The participation is an integral part of the social reality in which relations are not yet crystallized in social structures. The participation builds and is built on social transformation. The collaborative practices must vary, therefore, according to the social, historical and geographical contexts (MILANI, 2008; ANJOS, ANJOS and OLIVEIRA, 2013). The governance and participatory management are not synonymous, although complementary. Governance refers to political and institutional environment in which occur the disputes of interests and the conflicts to the coordination process. In its turn, this coordination process is expected to be capable to guarantee democratic management, the participation of different actors and share responsibilities with private sector and civil society (ARNS, 2009).

The social governance is a generic adjective of governance, to assign social and organizational arrangements of plural composition, which involves state and non-state actors, public and private, profitable or nonprofit and also citizens to the 
Territorial governance and social innovation in regional development processes in mining territories: a theoretic model under construction
Paula Pessoa de Castro Gentil | Liliane de Oliveira Guimarães Denise de Castro Pereira | Alexandre Magno Diniz Ivan Beck Ckagnazarof

public management (social control, defense of public interests, co-production of goods and services for the promotion of social welfare). Overcoming the traditional view that causes a dichotomy and polarizes the state and society, this form of governance can be presented as a new way to govern, in which the sense of public expresses and covers all spheres of society, generating public value as a result of public policies and civic results, in addition to socioeconomic development (KNOOP, 2011). The social management practice is, therefore, the path to the viability of democratic governance among the different actors belonging to the territory, in favor of economic and productive promotion. The social management represents the dialogical managerial process in which the decision-making authority is shared between the participants on any social system. The legitimacy of the political decisions has source in discussion processes, driven by the principles of inclusion, pluralism, equal participation, autonomy and common good (KRONEMBERGER, VELLELA and ZANI, 2012).

The concept of territorial governance arises from the analysis of the effects of proximity, historicity of territories and social, economic, political and institutional dynamics. At territorial dimension, the geographical proximity acts alongside another type of proximity, named "organized". The organized proximity appears beyond geophysical and political limits, where other kind of space operates, this one originated from a "fabric" (or "tissue", or "network") formed by people and groups in formal and informal collaborations, by the vivacity of local democratic practices and by the orientation that collectively organized actors follow as a way of building the future of the territory (GLON and PECQUEUR, 2016). In territorial governance, collective actors engage themselves to coordinate actions that allow solving local and regional issues that had arisen as consequences of the crowd, the specialization or the specification of territories. This is the reason why they choose to set on a certain strategy. The territorial governance happens, therefore, through decision-making processes and local action, which are not restricted to the governmental level (PIRES and NEDER, 2005; FUINI, 2013; OLIVEIRA, 2016). As members of this network of local actors, the mining companies, in addition to the socioeconomic and environmental interventions in the regional area, build positioning strategies that can encourage or undermine the collective dynamics of the territorial governance (SZARY, 2010).

The notion of territorial governance, next to the idea of social governance, but reasoned in territorial approach, refers, therefore, to a group of initiatives or actions that express the capacity of a society, organized in each territory, in a historical period, to manage public affairs. These actions constitute the territorial dynamics of the development. This management can be done by bringing together social, economic and institutional actors, involved in a pool and cooperative structure which stimulates the territorial development management process. This group, named "socio-territorial block" (DALLABRIDA, 2007), plays the local leadership and is composed of a set of heterogeneous actors with divergent interests, representing different segments of the territorially organized society. Such leadership are true socio-territorial power networks, becoming the major power structures that assume hegemonic position, thus becoming able to give political and ideological direction to the territorial development process (DALLABRIDA, 2007; CANÇADO, TAVARES and DALLABRIDA, 2013; DALLABRIDA, MARCHESAN, ROSETTO et al., 2015).

Disagreements and conflicts are inherent in any institutional arrangement based on partnership and shared decision spaces, either by different interests, or by pre-existing conflicts, or by the sometimes pioneering practice of the shared exercise of power and responsibility, or even by political and governance projects themselves (SOBRINHO and TEIXEIRA, 2017; VALLADARES and BOELENS, 2017). To deal with the divergence, the power struggles and natural conflicts, and try to define a future development project, consisting of socio-territorial pacts, territorially made agreements constitute the local/regional/ territorial development plan of a particular territory or region, built in different moments of its story (DALLABRIDA, 2007; CANÇADO, TAVARES and DALLABRIDA, 2013; DALLABRIDA, MARCHESAN, ROSETTO et al., 2015). The historic partnership legacy cannot be ignored when new forms of territorial governance come to occur. It is vital that lessons of the past are leveraged to the actors of all levels of governance, which can learn from their own successes and failures (AYRES and STAFFORD, 2012). There are different models and institutional practices for the exercise of territorial governance, such as, for example, development forums and councils, agencies or associations of local or regional development, diverse kinds of interest groups, cooperative associations, consortium, class associations, producers or business associations, among others (DALLABRIDA and BECKER, 2003).

The results of case studies on regional development processes, some in mining territories (ZANON, 2011; AYRES and STAFFORD, 2012; PIRES, 2015; DAVIES, 2005; PROVIN and KENIS, 2008; SCHIAVINATO, 2012, 2013; KRONEMBERGER, VELLELA and ZANI, 
Territorial governance and social innovation in regional development processes in mining territories: a theoretic model under construction
Paula Pessoa de Castro Gentil | Liliane de Oliveira Guimarães Denise de Castro Pereira | Alexandre Magno Diniz Ivan Beck Ckagnazarof

2012; MILANEZ and OLIVEIRA, 2011), highlight points that lead to the conclusion that the governance needs to be analyzed not only as transactions between actors and resources but also under the unique viewpoint of economic interest, to include issues such as power relations and the political culture.

It is assumed that the specificities of mining territories shape different forms of governance, which determine and are determined, in turn, by different processes of regional development. Each development model is territorial in nature, which means that each territory combines in a privileged form a certain arrangement of professional relations, social and cultural characteristics, industrial organization and institutionalized behaviors etc., which allow or resist to new possibilities (i.e. technological, economical) and changes (i.e. division of labor), and finally to social restructuring, allowing in turn that some mining territories do better than others. From this discussion follow the third and fourth theoretical propositions: (iii) The governance of a development planning process of a mining territory, through its structure and management mechanisms, is influenced by the involvement and exclusion of actors and social groups, by the composition between local / regional and national / international institutions, and by the way the development strategy was previously defined. Therefore, (iv) the governance model influences the articulation and the relationship between actors, social groups and institutions, and that being so, favors pacts and conflicts, impacting the regional development process in a mining territory in either a positive or a negative way.

It is desirable that the regional development processes be based on an innovative, shared and collaborative logic, a qualified idea of democracy and a greater role of civil society, while respecting the irreplaceable role of the State (DALLABRIDA, 2015). It is therefore necessary to investigate whether governance can be identified and recognized as an inducer or inhibitor of innovation in social practices, political decision-making mechanisms and social structures in territorial development projects (FUINI, 2013).

\section{The social innovation in regional development processes}

There is a growing academic and public interest in social innovation. Although not a new concept, having its sociological roots dating from the end of the 19th century, it was sparsely used until the 21st century. The idea of social innovation gains more attention than technological innovation when it refers to change and transformation in society and beyond the traditional economic focus (HOWALDT, KOOP and SCHWARZ, 2015; KLEIN, LAVILLE and MOULAERT, 2014; AYOB, TEASDALE and FAGAN, 2016; AVELINO, WITTMAYER, PEL et al., 2017; HAXELTINE, PEL, DUMITRU et al., 2017). At the same time, many groups of researchers are still reluctant to use the term because they consider its concept imprecise. For these groups, there is no agreement on the meaning of innovation and numerous uses for the word social (AYOB, TEASDALE and FAGAN, 2016).

The term innovation, in the academic literature, was popularized in the works of Joseph Schumpeter, especially in "The economic development theory" (first edition 1912). The author described the innovation as the fundamental element for economic development, understood as the process by which a more efficient combination of factors of production (land, work and capital) happens within private level, and turns into social benefit. The development would be, then, the result of a series of newness that could be introduced in an economic system, changing relations between producers and consumers (SCHUMPETER, 1977; TORRES, 2012).

This notion was being gradually expanded, and innovative processes have to be considered as being more social than individual by academic studies, putting evidence in the social creativity and in the institutional frames which promote innovation. In Neo-Schumpeterian context, within post 1970 studies, innovation has become the central weapon of competitiveness and growth (REIS, PASSONI and SHIKIDA, 2013).

Recent studies on technological and scientific innovations called attention to the importance of the environment and the networks. As the term "social innovation system" appears, comes also the understanding that the potential for innovation is very favored by the environment made by the universities, the financial system, the services providers, the set of regulations, the culture and the level of social cohesion, among others. After that, researchers began to use the notion of certain industries or certain territories as innovative potential, making registered the term "regional innovation system". This notion also allowed characterizing the specific environment of a territory or a sector in innovation planning or even a business category, constituted by private companies, public companies and public organizations, and social economic companies and organizations (LEVÉSQUE, 2011). 
Territorial governance and social innovation in regional development processes in mining territories: a theoretic model under construction
Paula Pessoa de Castro Gentil | Liliane de Oliveira Guimarães Denise de Castro Pereira | Alexandre Magno Diniz Ivan Beck Ckagnazarof

The innovation then began to be considered as an interdisciplinary category and as a process, made from the social interaction of distinct actors, as a nonlinear, complex, interactive and not necessarily scientific process (REIS, PASSONI and SHIKIDA, 2013). The social systems form entwined networks of relationships, where unexpected and unprecedented resources can arise. Sometimes, this social network becomes the essential element of the transformation of a territory (GLON and PECQUEUR, 2016). In this paper, innovation is considered as a conjecture of goals native to governments, business organizations and society, or social groups, members or not of the formal governance system. They believe the new possibilities/opportunities lead to the need for creating something new, such as products, processes, systems, or new ways of management, marketing, logistics, among others. Most of times, this innovative movement means new ways of articulation, action, interaction, and especially new models of governance (CRESPY, HERALD and PERRY, 2007; ALMEIDA, SILVA and OLIVEIRA, 2014).

The concept of territorial innovation models-TIM, and the theoretical body developed from it, is a practical example of an innovative perspective to territorial governance in regional development process (MOULAERT and SEKIA, 2003; CREVOISIER, 2014). According to TIMs theory, the local institutional dynamics play an important role. The development in these models is endogenous, i.e., is not caused, induced or directed by actors outside the region. It possesses its own logic, a so-called autonomy, which can only be understood by actors, the relations and the dynamics within the region (MOULAERT and SEKIA, 2003; EUROPEAN COMMISSION, 2005). From this approach, it is no longer possible to consider innovation as a mere economic phenomenon independent of the territory. Much of the theory produced about the territorial innovation models date from mid-1980 until the end of 1990. In territorial innovation approach, in addition or in interaction with economic attributes privileged by the theories of regional development, the environment is enhanced with a new concept of socio-cultural values and of local history traces (MOULAERT and SEKIA, 2003). From the beginning of 2000 to today, new study questions and new viewpoints have emerged as questioning the theory of innovation territorial models (CREVOISIER, 2014).

In theory that gave support to TIMs, the development occurs through innovation, more particularly of technological innovation. The latest understanding, however, derived from empirical analysis, has demonstrated that innovation happens by nontechnological elements, it occurs by socio-cultural dynamics (CREVOISIER, 2014). In this sense, there was still a theoretical group that took the path of an alternative approach to innovation in territorial development processes, giving prominence to notions of social innovation.

In general, social innovation represents a new approach, practice, or intervention, a new response to a social situation considered unsatisfactory or to a social need or aspiration that can manifest itself in all sectors of society. It concerns the well-being of individuals or communities and means the transition to something better, such as a more democratic, more sustainable society. It can be procedural, when, in example, it results from the cooperation between several actors, in a collective process of learning and creation of knowledge. But it can also be organizational, inter-organizational, institutional and related to governance. It may be the origin of a national system, a social enterprise or a system as in the social economy, based on solidarity. But it can also manifest itself in something tangible, like a technology, or a product, in goods and services. Considered by some authors as an opportunity for action or intervention, set of actions or practices, in order to modify social relations, to promote social inclusion and cohesion, to transform an established social framework, or to propose new cultural orientations and even market, thus generating new social values (CLOUTIER, 2003; HOWALDT, KOOP and SCHWARZ, 2015; KLEIN, LAVILLE and MOULAERT, 2014; JENSON, 2015; EVERS, 2015; HART, RAMOROKA, JACOBS et al., 2015; BOUCHARD, TRUDELLE, BRIAND et al., 2015; EDWARDS-SCHACHTER and WALLACE, 2017).

More recently, new approaches have brought to the debate the explanation of the processes of institutionalization of social innovation (BOUCHARD, TRUDELLE, BRIAND et al., 2015) and the overlapping ideas of structural change and social transformation (HOWALDT, KOOP and SCHWARZ, 2015; HAXELTINE, PEL, DUMITRU et al, 2017; AVELINO, WITTMAYER, PEL et al., 2017), including what they call the "empowerment" of social actors. These approaches make up the new concept of transformative social innovation, the process of challenging, changing or replacing the dominance of existing institutions in a specific social and material context. New practices deconstruct and modify previous institutional arrangements, opening space for new paradigms of development. Not all social innovation initiatives and networks start with transformative ambition, and of those who do, only a few can achieve truly transformative impacts. In addition, the risks of capture and co-option are strong. Social change is a process of change in the social structure of a society in its constitutive institutions, cultural patterns, associated social actions and consciousness. Depending on the circumstances of social change, interests, politics and power, 
Territorial governance and social innovation in regional development processes in mining territories: a theoretic model under construction
Paula Pessoa de Castro Gentil | Liliane de Oliveira Guimarães Denise de Castro Pereira | Alexandre Magno Diniz Ivan Beck Ckagnazarof

social ideas and successful social innovations can be used and transformed so that it can eventually become institutionalized as a regular social practice. So it's no longer an innovation, it's become routine (HOWALDT, KOOP and SCHWARZ, 2015; KLEIN, LAVILLE and MOULAERT, 2014; HAXELTINE, PEL, DUMITRU et al., 2017).

One of the central objects of the theoretical model proposed for future research is social innovation, intimately related to territorial and institutional governance, rooted in the heart of local and regional issues, capable of deeply touching and modifying the social structures of a mining territory and lead the transformation. So, the final couple of propositions to compose the theoretic model are: (v) Considering a regional development process in a specific mining territory, the nature of the relationship between territorial governance and social innovation can be of cause and effect (which means that the governance favors or inhibits the innovation) or identity (which means that the innovation is the governance itself). Besides that, (vi) social innovation in a planned process of regional development can generate new social and economic values, modifying the local social structures, favoring the decrease or extinction of local dependence and negative influence of the extractive industry, and even the transformation of the territory.

This means the territory is free to be no longer just a mining territory.

\section{FINAL CONSIDERATIONS}

Mining activity presents itself to a territory as an inevitable destination, an award-winning ticket, a shortcut to prosperity, a relentless source of energy and employment, a provider father, a benevolent mother. However, the dream embedded in this image that endures in the history of mankind does not survive the light that affects the eyes at the exit of each dark tunnel. This history, often poorly or partially told, has increasingly become a recurring nightmare in the life trajectories of workers and communities who have lived and still live in regions where mineral extractive industries predominate. Researchers from diverse academic areas have been dedicated to analyze the experiences of mining territories, either at the imminence of a new venture, during its operation or after the mine closure. The theoretical model presented in this article intends to contribute to this discussion by offering, from the administration field, a structure of analysis that correlates essential factors with the concept of regional development of territories where mining activity prevails- governance and innovation, as yet little exploited beyond the economic bias. Territorial governance and social innovation are therefore related to the dynamics of a given regional development process in a specific mining territory (Figure 1). The structure allows to give shape to an analytical content, through six propositions, presented in pairs, thus making the triangulation of aspects that allow a deeper understanding of the experience lived by the territory and opens a window for practical contributions in new experiences. 
Territorial governance and social innovation in regional development processes in mining territories: a theoretic model under construction
Paula Pessoa de Castro Gentil | Liliane de Oliveira Guimarães Denise de Castro Pereira | Alexandre Magno Diniz Ivan Beck Ckagnazarof

Figure 1

Territorial governance and social innovation in regional development processes in mining territories

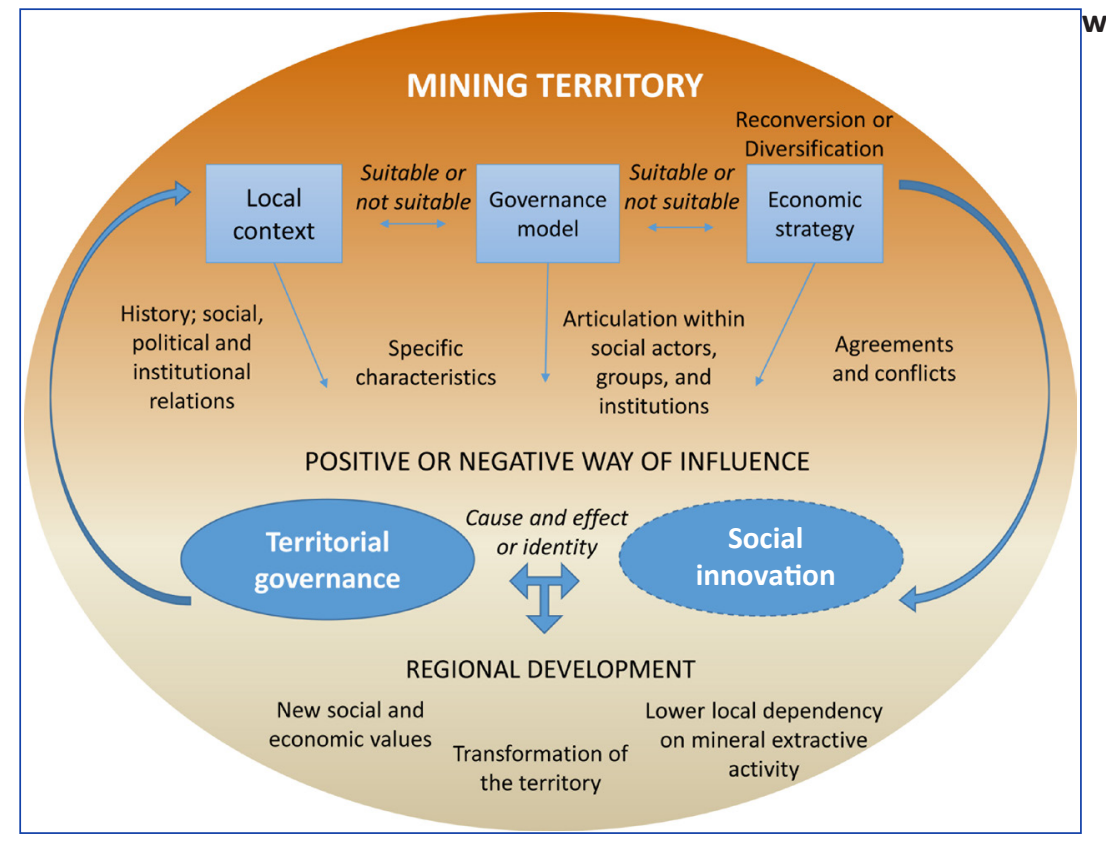

Source: Elaborated by the authors.

Some specific characteristics of a mining territory can limit and even prevent its regional development. As a result, the strategy for regional development in a mining territory should seek a priori mechanisms to minimize local dependency and negative influence of the mining activity. The governance of a development planning process of a mining territory, through its structure and management mechanisms, is influenced by the involvement and exclusion of actors and social groups, by the composition between local / regional and national / international institutions, and by the way the development strategy was previously defined. Therefore, the governance model influences the articulation and the relationship between actors, social groups and institutions, and consequently favors pacts and conflicts, impacting on the regional development process in a mining territory in either a positive or a negative way. Considering a regional development process in a specific mining territory, the nature of the relationship between territorial governance and social innovation can be of cause and effect (where the governance favors or inhibits the innovation) or identity (where the innovation is the governance itself). Besides that, social innovation in a planned process of regional development can generate new social and economic values, modifying the local social structures, favoring the decrease or extinction of local dependence and negative influence of the extractive industry, and even the transformation of the territory.

We recognize that the proposed model presents limitations that we believe are to overcome with the contributions of the refinements as it is tested. One of the possibilities of improvement would be to include in the propositions, specific questions of each theme, referring to the territory to be analyzed, like examples related to the Brazilian reality, the fragility of local governmental organizations and their limited capacity for action in Brazil, especially with the current tax model, or even the false neutrality of the Brazilian State in the articulation with civil society and private organizations, or even the dynamics of the political system and the electoral schedule that establishes abrupt changes and discontinuity of public policies. Issues such as these are likely to be addressed in the analysis and will contribute to the improvement of this proposal.

This model proposes to serve as a guide for empirical studies carried out in the same context, which is the reality of mining territories, in support of comparative or parallel analysis of different case studies. It is important to diagnose how these processes occur in different realities, both geographic and cultural space and in the diverse extractive processes. It is hoped that the results of studies of this nature may be useful not only to the increase of knowledge but also to the practice of plans and development processes in mining activity territories, so that one day the paradoxical inequality between profitability of business and the impoverishing effects of multiple natures on the territory can be broken or at least challenged. 
Territorial governance and social innovation in regional development processes in mining territories: a theoretic model under construction
Paula Pessoa de Castro Gentil | Liliane de Oliveira Guimarães Denise de Castro Pereira | Alexandre Magno Diniz Ivan Beck Ckagnazarof

\section{REFERENCES}

AFFUSO, A.; CAPELLI, R.; FRATESI, U. Globalization and competitive strategies in european vulnerable regions. Regional Studies, v. 45, n. 5, p. 657-675, 2011.

ALMEIDA, M. L.; SILVA, J. L. G.; OLIVEIRA, E. A. A. Q. A inovação como fator de desenvolvimento regional. Revista Brasileira de Gestão e Desenvolvimento Regional, v. 10, p. 314-350, 2014.

ANJOS, F. A. D.; ANJOS, S. J. G. D.; OLIVEIRA, J. P. D. A abordagem sistêmica no processo de planejamento e gestão de territórios urbanos turísticos. Rosa dos Ventos-Turismo e Hospitalidade, v. 5, n. 3, p. 390-407, July/Sept. 2013.

ARIAS, M.; ATIENZA, M.; CADEMARTORI, J. Large mining enterprises and regional development in Chile: between the enclave and cluster. Journal of Economic Geography, v. 14, n. 1, p. 73-95, 2014.

ARNS, P. C. Governança democrática e desenvolvimento territorial: avanços e limites das iniciativas brasileiras. In: ZAPATA, T. (org.). Desenvolvimento local e a nova governança. Recife: IADH, 2009. Available at: <http://www.iadh.org.br/files/Paulo_Cesar_Arns_ Revisado.pdf>. Accessed on: July 05, 2018.

ARTUKHOVA, N. et al. Concept Model of Mining Monotowns Sustainable Development. In: INTERNATIONAL INNOVATIVE MINING SYMPOSIUM, 3., 2018, Kemerovo. Proceedings... Kemerovo: E3S Web of Conferences, 2018. Available at: <https://www.e3s-conferences.org/10.1051/ e3sconf/20184104008>. Accessed on: July 05, 2018.

AVELINO, F. et al. Transformative social innovation and (dis) empowerment technological. Forecasting \& Social Change, 2017. Available at: <http://dx.doi.org/10.1016/j.techfore.2017.05.002>. Accessed on: July 05, 2018.

AVILA, E. A. C. Novos desafios a aglomeraciones em torno a la minería. In: BUITELAAR, R. Aglomeraciones mineras y desarrollo local en América Latina. Alfaomega: México, 2001, p. xix-xxi.

AYOB, N.; TEASDALE, S.; FAGAN, K. How social innovation 'came to be': tracing the evolution of a contested concept. Journal of Social Politics, v. 45, n. 4, p. 635-653, 2016.

AYRES, S.; STAFFORD, I. Managing complexity and uncertainty in regional governance networks: a critical analysis of state rescaling in England. Regional Studies, v. 48, n. 1, p. 219-235, 2014.

BAETEN, G.; SWYNGEDOUW, E.; ALBRECHTS, L. Politics, institutions and regional restructuring processes: from managed growth to planned fragmentation in the reconversion of Belgium's last coal mining region. Regional Studies, v. 33, n. 3, p. 247-258, 1999.

BECKER, L. C.; PEREIRA, D. C. O projeto Minas-Rio e o desafio do desenvolvimento territorial integrado e sustentado: a grande mina em Conceição do Mato Dentro. In: FERNANDEZ, F. R. C.; ENRIQUEZ, M. A. R. S; ALAMINO, R. C. J. (Eds.). Recursos minerais e sustentabilidade territorial. Brasília, DF: MCT-CETEM, 2011. p. 229-258.

BENTLEY, G. Fitting the piece in the jigsaw puzzle? the governance of local economic development policy and regeneration in Birmingham. Local Economy, v. 20, n. 2, p. 238-243, 2005.

BITTENCOURT, C. Fundos Sociais da mineração e sociodeterminação do território. Le Monde Diplomatique Brasil, São Paulo, July 07,
2014. Available at: <http://www.diplomatique.org.br>. Accessed on: July 05, 2018.

BORGES, S. O desastre da barragem de rejeitos em Mariana, Minas Gerais: aspectos socioambientais e de gestão na exploração de recursos minerais. Cuadernos de Geografía: Revista Colombiana de Geografía, v. 27, n. 2, p. 301-312, 2018.

BOUCHARD, M. et al. A relational database to understand social innovation and its impact on social transformation. In: NICHOLLS, A. et al. (Eds.). New Frontiers in Social Innovation Research. Basingstoke: Palgrave Macmillan, 2015.

BRUGUÉ, Q.; GOMÁ, R. Nuevas formas de gobernar: límites y oportunidades. In: FLEURY, S.; SUBIRATS, J.; BLANCO, I. (Eds.). Respuestas locales a inseguridades globales: innovación y cambios en Brasil y España. Barcelona: Fundación CIDOB, 2008. p. 265-284.

BUITELAAR, R. M. Conceptos, inquietudes y aglomeraciones em torno de la minería. In: BUITELAAR, R. M. (Comp.). Aglomeraciones mineras y desarrollo local en América Latina. México, DF: Alfaomega: 2001. p. 1-15.

CAMAGNI, R. On the concept of territorial competitiveness: sound or misleading? Urban Studies, v. 39, n. 13, p. 2395-2411, 2002.

CANÇADO, A.; TAVARES, B.; DALLABRIDA, V. Gestão social e governança territorial: interseções e especificidades teórico-práticas. Revista Brasileira de Gestão e Desenvolvimento Regional, v. 9, n. 3, p. 313-353, 2013.

CENTRO DE GESTÃO E ESTUDOS ESTRATÉGICOS - CGEE. Relatório preparado para o Projeto BRA/0045 Contrato 2002/001604. Brasília, DF: CGEE, 2002. Available at: <www.cgee.org.br/arquivos/ estudo011_02.pdf>. Accessed on: July 05, 2018.

CHAPAIN, C.; MURIE, A. The impact of factory closure on local communities and economies: the case of the MG Rover Longbridge closure in Birmingham. Policy Studies, v. 29, n. 3, p. 305-317, Sept. 2008.

CHAUTARD, G.; ZUINDEAU, B. L'enjeu d'une reconversion durable des territoires de tradition industrielle : l'exemple du bassin minier du Nord - Pas-de-Calais. Espace, populations, sociétés, Les populations des bassins d'industries Lourdes, n. 3, p. 325-339, 2001.

CLOUTIER, J. Qu'est-ce que l'innovation sociale? Québec: Crises, 2003. (Collection Études théoriques, n. ET0314). Available at: <www. crises.uqam.ca>. Accessed on: July 05, 2018.

COENEN, L.; MOODYSSON, J.; MARTIN, H. Path renewal in old industrial regions: possibilities and limitations for regional innovation policy. Regional Studies, v. 49, n. 5, p. 850-865, 2015.

CRESPY, C.; HERAUD, J.; PERRY, B. Multi-level governance, regions and science in France: between competition and equality. Regional Studies, v. 41, n. 8, p. 1069-1084, 2007.

CREVOISIER, O. Beyond territorial innovation models: the pertinence of the territorial approach. Regional Studies, v. 48, n. 3, p. 551-561, 2014.

CUNHA, A.; GUEDES, G. Mineração e os objetivos de desenvolvimento sustentável: o desafio da diversificação econômica em Itabira (MG). Rio de Janeiro: CETEM/MCTIC, 2017. 
Territorial governance and social innovation in regional development processes in mining territories: a theoretic model under construction
Paula Pessoa de Castro Gentil | Liliane de Oliveira Guimarães Denise de Castro Pereira | Alexandre Magno Diniz Ivan Beck Ckagnazarof
DALLABRIDA, V. A gestão social dos territórios nos processos de desenvolvimento territorial: uma aproximação conceitual. Sociedade, Contabilidade e Gestão, v. 2, n. 2, p. 44-60, 2007.

DALLABRIDA, V. Territory planning and management: the theory debate in Brazil and a prospect of practice according to theoretical contributions on territorial governance. Revista Brasileira de Gestão e Desenvolvimento Regional, v. 11, n. 4, p. 51-77, 2015.

DALLABRIDA, V. R.; BECKER, D. F. Governança territorial: um primeiro passo na construção de uma proposta teórico-metodológica. Desenvolvimento em questão, v. 1, n. 2, p. 73-97, 2003.

DALLABRIDA, V. et al. Gestão territorial e multiescalaridade na descentralização político-administrativa de dois Estados do Sul do Brasil. In: COLÓQUIO INTERNACIONAL SOBRE PODER LOCAL, 11., 2009. Anais... Salvador: CIAGS/UFBA, 2009.

DALLABRIDA, V. et al. Governança nos territórios ou governança territorial: distância entre concepções teóricas e a prática. In: DALLABRIDA, V. (Org.). Indicação geográfica e desenvolvimento territorial: reflexões sobre o tema e potencialidade no Estado de Santa Catarina. São Paulo: LiberArs, 2015. p. 23-40.

DAVIS, G. V. Where once there were mountains: the grassroots struggle against mountaintop removal coal mining in central Appalachia. Environmental Politics, v. 18, n. 1, p. 135-140, 2009.

DAVIES, J. S. Local governance and the dialectics of hierarchy, market and network. Policy studies, v. 26, n. 3-4, p. 311-335, 2005.

DEMO, P. Metodologia do conhecimento científico. São Paulo: Atlas, 2000.

DEPARTAMENTO NACIONAL DE PRODUÇÃO MINERAL - DNPM. Sumário mineral. Brasília, DF: DNPM, 2016. Available at: <http:// www.dnpm.gov.br>. Accessed on: July 05, 2018.

ECHEVARRIA, C. Desafíos del desarrollo sustentable em las regiones mineras. In: BUITELAAR, R. M. (Comp.). Aglomeraciones mineras y desarrollo local en América Latina. México, DF: Alfaomega: 2001. p. Xv-xvii.

EDWARDS-SCHACHTER, M.; WALLACE, M. 'Shaken, but not stirred': six decades defining social innovation. Technological Forecasting and Social Change, v. 119, p. 64-79, June 2017. Available at: <https://doi. org/10.1016/j.techfore.2017.03.012>. Accessed on: July 05, 2018.

EISENHARDT, K. M. Building theories from case study research. Academy of Management Review, Standford, v. 14, n. 4, p. 532 550, 1989.

EJDEMO, T.; SODERHOLM, P. Mining investment and regional development: a scenario-based assessment for Northern Sweden. Resources Policy, v. 36, p. 14-21, 2011.

ENRIQUÉZ, M. A. R. S. Maldição ou dádiva? os dilemas do desenvolvimento sustentável a partir de uma base mineira. 2007. 249 p. Thesis (Doctor Degree in Sustainable Development) - Centro de Desenvolvimento Sustentável, Universidade de Brasília, Brasília, 2007. Available at: <http://repositorio.unb.br/ bitstream/10482/6417/1/2007_MariaAmeliaEnriquez.pdf>. Accessed on: July 05, 2018.

EUROPEAN COMMISSION. EU research on social sciences and humanities: social innovation, governance and community building. Luxemburg: Office for Official Publications of the European Communities, 2005.

EVERS, A.; EWERT, B. Social Innovation for Social Cohesion. In: NICHOLLS, A. et al. (Eds.). New Frontiers in Social Innovation Research. Basingstoke: Palgrave Macmillan, 2015. p. 107-127.

FARIA, D. M.; ARAÚJO, F. O. Da bacia mineira à bacia da cachaça: desenvolvimento e cultura em regiões mineiras. Via@, v. 1, n. 7, 2015. Available at: <http://viatourismreview.com/pt/2015/09/ art6/>. Accessed on: July 05, 2018.

FISCHER, T. Gestão contemporânea, cidades estratégicas: aprendendo com fragmentos e reconfigurações do local. In: FISCHER, T. (Org.). Gestão contemporânea: cidades estratégicas e organizações locais. Rio de Janeiro: FGV, 1996. p. 13-23.

FUINI, L. A governança e o território: reflexões sobre uma abordagem de pesquisa. Revista de Desenvolvimento Econômico, v. 28, n. 15 p. 86-99, 2013.

GIL, A.C. Como elaborar projetos de pesquisa. 3. ed. São Paulo: Atlas, 1994.

GLON, E. ; PECQUEUR, B. Proximités, ressources et territoires créatifs. In: GLON, E.; PECQUEUR, B. Au cœur des territoires créatifs: proximités et ressources territoriales. Rennes: Presses Universitaires de Rennes, 2016. p. 11-30.

GODOI, C. K.; BALSINI, C. P. V. A metodologia qualitativa em estudos organizacionais. In: ENCONTRO DE ESTUDOS ORGANIZACIONAIS, 3., 2004, Atibaia. Anais... Atibaia: ANPAD, 2004. Available at: <http:// www.anpad.org./eventos>. Accessed on: Sept. 12, 2018.

GODOY, A. S. Introdução à pesquisa qualitativa e suas possibilidades. Revista de Administração de Empresas, São Paulo, v. 35, n. 2, p. 57-63, 1995.

GOODE, W. J.; HATT, P. K. Métodos em Pesquisa Social. 4. ed. São Paulo: Nacional, 1973. p. 420-433.

GREENWOOD, E. Metodologia de la investigacion social. Buenos Aires: Paidós, 1973.

HAESBAERT, R. Região e regionalização num mundo desterritorializado. O urbano e o regional no Brasil contemporâneo: mutações, tensões, desafios. Salvador: EDUFBA, 2007. p. 37-58.

HART, T. G. B. et al. Revealing the social face of innovation. South African Journal of Science, Pretoria, v. 111, n. 9-10, p. 1-6, 2015. Available at: <http://dx.doi.org/10.17159/SAJS.2015/20140126>. Accessed on: July 05, 2018.

HAXELTINE, A. et al. Towards a TSI theory: a relational framework and 12 propositions. Rotterdam: TRANSIT, 2017. (Working Paper, n. 16).

HOWALDT, J.; KOPP, R.; SCHWARZ, M. Social innovations as drivers of social change-exploring Tarde's contribution to social innovation. In: NICHOLLS, A. et al. (Eds.). New Frontiers in Social Innovation Research. Basingstoke: Palgrave Macmillan, 2015. p. 29-51.

INSTITUTO BRASILEIRO DE MINERAÇÃO-IBRAM. Informação e análises da economia mineral brasileira. 6. ed. Brasília, DF: IBRAM, 2012. Available at: <http://www.ibram.org.br>. Accessed on: July 05, 2018.

JENSON, J. Social innovation: redesigning the welfare diamond. In: NICHOLLS, A. et al. (Eds.). New Frontiers in Social Innovation Research. Basingstoke: Palgrave Macmillan, 2015. p. 89-106. 
Territorial governance and social innovation in regional development processes in mining territories: a theoretic model under construction
Paula Pessoa de Castro Gentil | Liliane de Oliveira Guimarães Denise de Castro Pereira | Alexandre Magno Diniz Ivan Beck Ckagnazarof
KLEIN, J.; LAVILLE; J.; MOULAERT, F. L'innovation sociale. Toulouse: Editions ères, 2014.

KNOOP, G. Governança social, território e desenvolvimento. Perspectivas em Políticas Públicas, v. 4, n. 8, p. 53-74, 2011.

KRONEMBERGER, T. S.; VILLELA, L. E.;ZANI, F. B. APLs e Desenvolvimento Territorial: um estudo sobre o programa território da cidadania norte do Rio de Janeiro. Desenvolvimento em Questão, v. 10, n. 21, p. 28-60, 2012.

LAMBERT, A.; BOULANGER, P. La dynamique d'un développement non durable : le Borinage de 1750 à 1990. Espace, populations, sociétés, Les populations des bassins d'industries Lourdes, n. 3, p. 311-324, 2001.

LEFEBVRE, H. The production of space. 3 .ed. Oxford: Blackwell, 1993.

LÉVESQUE, B. Le potentiel d'innovation dês enterprises et des organisations de l'economie sociale: éléments de problématique. Revista Alcance, v. 18, p. 362-386, 2011.

LIEFOOGHE, C. Old industrial regions (II) - Nord-pas-de-Calais. Regions Magazine, v. 259, n. 1, p. 13-16, 2005.

MARKUSEN, A. Áreas de atração de investimentos em um espaço econômico cambiante: uma tipologia de distritos industriais. Nova economia, v. 5, n. 2, p. 9-44, 1995.

MILANEZ, B.; OLIVEIRA, J. A. P. Ambiente, pessoas e labor: APLs além do desenvolvimento econômico na mineração de opalas em Pedro II, no Piauí. Cadernos EBAPE.BR, Rio de Janeiro, v. 7, n. 4, p. 527-546, 2009.

MILANI, C. R. O princípio da participação social na gestão de políticas públicas locais: uma análise de experiências latino-americanas e europeias. Revista de Administração Pública, Rio de Janeiro, v. 42, n. 3, p. 551-579, 2008.

MOULAERT, F.; SEKIA, F. Territorial innovation models: a critical survey. Regional Studies, v. 37, n. 3, p. 289-302, 2003.

NUSSBAUMER, J.; MOULAERT, F. Integrated area development and social innovation in European cities. City, v. 8, n. 2, p. 249-257, 2004.

OLIVEIRA. E. Territorial governance across Europe: pathways, practices and prospects. Regional Studies, v. 50, n. 11, p. 1943-1944, 2016.

PEREIRA, D. C.; PEREIRA, L. F. Cenários socioambientais em municípios com mineração: complexidades estratégicas e possibilidades transformadoras. In: SEMINÁRIO INTERNACIONAL DE RECONVERSÃO DE TERRITÓRIOS, 1., 2012, Belo Horizonte. Anais... Belo Horizonte: PUC Minas, 2012.

PIRES, E. L. S. A recomposição das escalas de governança, Estado e desenvolvimento territorial no Brasil. GeoTextos, v. 11, n. 1, p. 113-137, 2015.

PIRES, E. L. S.; NEDER, R. T. A governança territorial no Brasil: As instituições, os fatos e os mitos. Geografia e Pesquisa, v. 2, n. 2, 2008.

PROVIN, K. G.; KENIS, P. Modes of network governance: structure, management, and effectiveness. Journal of public administration research and theory, v. 18, n. 2, p. 229-252, 2008.

REIS, M. C.; PASSONI, W. C.; SHIKIDA, M. A. M. Fomentando a cultura da inovação: notas de pesquisa. In: CONGRESO LATINO-AMERICANO DE SOCIOLOGÍA, 29., 2013, Santiago. Anais... Santiago: ALAS, 2013.
ROCHA, L. B.; ALMEIDA, M. G. Cultura, mundo vivido e território. In: SIMPÓSIO NACIONAL SOBRE GEOGRAFIA, PERCEPÇÃO E COGNIÇÃO DO MEIO AMBIENTE, 2008, Londrina. Anais... Londrina: SINPEC, 2008.

SANT'ANNA, A. S. et al. Liderança e reconversão de funções econômicas de cidades: o caso Tiradentes (MG). Nova Lima: FDC/FAPEMIG, 2011. (Relatório de pesquisa).

SANTOS, A. R. Metodologia científica: a construção do conhecimento. Rio de Janeiro: DP\&A, 1999.

SCHIAVINATO, M. Governança Territorial e Novos Processos de Desenvolvimento: um Estudo de Caso do Território da Cidadania Vale do Jamari-Rondônia. In: ENCONTRO NACIONAL DA ASSOCIAÇÃO NACIONAL DE PÓS-GRADUAÇÃO E PESQUISA EM AMBIENTE E SOCIEDADE, 6., 2012, Belém. Anais... Pará: ANPPAS, 2012. Available at: <http://www.anppas.org.br/encontro6/anais/ARQUIVOS/GT2 1381-1178-20120629150505.pdf>. Accessed on: July 05, 2018.

SCHIAVINATO, M. Desenvolvimento territorial: inovação ou imposição? um olhar sobre as abordagens territoriais do desenvolvimento rural na América Latina. 2013. 204 f. Thesis (Doctor Degree in Sustainable Development) - Centro de Desenvolvimento Sustentável, Universidade de Brasília, 2013. Available at: <http://www.repositorio.unb.br/ bitstream/10482/14035/1/2013_MonicaSchiavinatto.pdf>. Accessed on: July 05, 2018.

SCHMITT, G. Inégalités écologiques et utilisation du sol : situation de la région Nord-Pas de Calais. Développement durable et territoires, Inégalités écologiques, inégalités sociales, Dossier 9, 2007. Available at: <http://developpementdurable.revues.org/3472>. Accessed on: July 05, 2018.

SCHUMPETER, J. A. Teoria do desenvolvimento econômico: uma investigação sobre lucros, capital, crédito, juto e ciclo econômico. São Paulo: Nova Cultural, 1977.

SHILLING, E. Future concepts in Russia and Germany: different approaches to planning in the global society. Twenty-First Century Society, v. 3, n. 2, p. 131-142, 2008.

SILVA, R et al. A nova fronteira da mineração e os velhos dilemas do desenvolvimento no norte de Minas Gerais. In: CONGRESSO EM DESENVOLVIMENTO SOCIAL: ESTADO, MEIO AMBIENTE E DESENVOLVIMENTO, 5., 2016, Montes Claros. Anais... Montes Claros: UNIMONTES, 2016. p. 5-18.

SOBRINHO, M.; TEIXEIRA, M. Partnership inside governance spaces: the case of the municipal development forum of Igarapé-Açú, Pará, Amazônia. Cadernos EBAPE.BR, Rio de Janeiro, v. 14, n. 3, p. 720735, July/Sept. 2017.

SOY, S. K. The case study as a research method. Texas: University of Texas, 1997. Available at: <http://www.gslis.utexas.edu? ssoy/ useusers/1391d1b.htm>. Accessed on: July 05, 2018.

SZARY, A. Les entreprises minières dans la gouvernance territoriale - Entre négociations de pouvoir et rivalités territoriales, qui porte le développement aux habitants ?. Revue Géographique de l'Est, v. 50, n. 3-4, 2010.

TAVARES, H. M. Estratégias de desenvolvimento regional. Da grande indústria ao Arranjo Produtivo Local? Revista Brasileira de Gestão e Desenvolvimento Regional, v. 7, n. 1, p. 50-68, 2011. 
Territorial governance and social innovation in regional development processes in mining territories: a theoretic model under construction
Paula Pessoa de Castro Gentil | Liliane de Oliveira Guimarães Denise de Castro Pereira | Alexandre Magno Diniz Ivan Beck Ckagnazarof
TORRES, R. L. A “inovação" na teoria econômica: uma revisão. In: ENCONTRO DE ECONOMIA CATARINENSE, 6., 2012, Joinvile. Anais... Joinville: APEC, 2012.

VALLADARES, C.; BOELENS, R. Extractivism and the rights of nature: governmentality, 'convenient communities' and epistemic pacts in Ecuador. Environmental Politics, v. 26, n. 6, p. 1015-1034, 2017. Available at: <http://dx.doi.org/10.1080/09644016.2017.1338384>. Accessed on: July 05, 2018.

VILLELA, R.; GIUSTI, F. Mineração de cobre em Canaã dos Carajás, desenvolvimento e impactos socioeconômicos: para quem? In:
ENCONTRO NACIONAL DE ESTUDOS POPULACIONAIS, 20., 2016, Foz do Igauçu. Anais... Foz do Igauçu: ABEP, 2016.

WALSH, C.; ALLIN, S. Strategic Spatial Planning: Responding to Diverse Territorial Development Challenges: Towards an Inductive Comparative Approach. International Planning Studies, v. 17, n. 4, p. 377-395, 2012.

ZANON, B. Infrastructure network development, re-territorialization processes and multilevel territorial governance: a case study in Northern Italy. Planning Practice \& Research, v. 26, n. 3, p. 325347, 2011.

Paula Pessoa de Castro Gentil

ORCID: https://orcid.org/0000-0003-1724-8857

PhD and MS in Administration in the Post-Graduate Program in Administration at Pontifical Catholic University of Minas Gerais (PUC Minas), Belo Horizonte-MG, Brazil. E-mail: castropp@uol.com.br

Liliane de Oliveira Guimarães

ORCID: https://orcid.org/0000-0002-3346-2207

PhD in Administration from School of Business Administration at Getulio Vargas Foundation of São Paulo (FGV EAESP); Professor in the Graduate Program in Administration at Pontifical Catholic University of Minas Gerais (PUC Minas), Belo Horizonte - MG, Brazil. E-mail: lilianeog@pucminas.br

Denise de Castro Pereira

ORCID: https://orcid.org/0000-0002-2541-6374

PhD in Sociology from Institute of Philosophy and Social Sciences at Federal University of Rio de Janeiro (UFRJ); FAPEMIG Fellow-Visiting Researcher of the Environmental Issues Studies Group at Federal University of Minas Gerais (UFMG), Belo Horizonte - MG, Brazil. E-mail: dpereirapuc@gmail.com

Alexandre Magno Alves Diniz

ORCID: https://orcid.org/0000-0002-5649-7736

PhD in Geography from Arizona State University (ASU); Adjunct Professor IV in the Postgraduate Program in Geography at Pontifical Catholic University of Minas Gerais (PUC Minas), Belo Horizonte-MG, Brazil. E-mail: alexandremadiniz@gmail.com

Ivan Beck Ckagnazaroff

ORCID: https://orcid.org/0000-0002-8179-269X

PhD in the Doctoral Programme Aston Business School-Aston University; Full Professor in the Department of Administrative Sciences and CEPEAD at Federal University of Minas Gerais (UFMG), Belo Horizonte-MG, Brazil. E-mail: ivanbeck00@gmail.com 